\title{
The Mozi and Just War Theory in Pre-Han Thought
}

\author{
Chris Fraser \\ University of Hong Kong
}

\section{Introduction}

China's Warring States era (481-221 BCE) was marked by cruel, destructive, recurring warfare between the seven major warring states and numerous minor states. This incessant violence gave rise to an impassioned anti-aggression discourse led by the early Warring States philosopher and social activist Mozi and his followers, the most well-known critics of armed aggression. Initially, the Mohists may have simply opposed all military aggression. Later, however, they developed the more nuanced view that, although unprovoked aggression is wrong, defensive warfare-including defensive assistance to cities or states other than one's own-and punitive aggression are sometimes justified. The writings collected in the Mozi 墨子 implicitly present an elaborate set of criteria by which to evaluate the justification for war. This article will examine these criteria and explore the extent to which they overlap with justifying conditions widely accepted in contemporary just war theory. One key finding will be that the Mohist criteria are so stringent that offensive war can be justified only very rarely and even defensive war is not always warranted.

The Mohists initiated a discourse on the moral justification for war to which a wide range of early texts contributed. Here I will review the brief but significant treatment of these topics in pre-Han Daoist, Confucian, and military texts. I will then explore in detail how several sections of The Annals of Lü Buwei 呂氏春秋 seek to articulate a conception of just or righteous arms (yi bing 義兵) as an alternative to the Mohist position, rejecting in particular the Mohist privileging of defensive over offensive war. I will argue that, with minor clarifications or refinements, the Mohist view adequately answers the criticisms in the Annals and underscores a problem concerning the authority for offensive war that the Annals overlooks. At the same time, I will highlight conceptual features of early Chinese justifications for warmost importantly, the conceptual analogy between just war and criminal punishment - that reflect genuine, deep problems for the justification of aggression.

Warring States texts are generally anthological and of uncertain date, their various sections having been written and compiled gradually, sometimes over many years, by multiple, anonymous hands. For these reasons, this study is organized mainly thematically, rather than chronologically, and will focus on the views expressed in texts, not the positions of specific historical figures. I begin from Mohist views on war because Mozi and his followers were the most prominent early critics of unrestrained warfare and their texts present detailed arguments for their views. After surveying philosophical views on war from a range of other texts, I examine the arguments of the Annals at length, partly because of their rich detail, partly because of their historical significance. The Annals is a compendium of writings produced by a team of scholars sponsored by Lü Buwei, chief minister of the state of Qin, which eventually conquered all other rival states to unify China in 221 BCE. Unlike almost all other pre-Han philosophical texts, the "almanac" sections of the Annals-which include the essays on warfare - can be assigned a fairly precise date, as they are known to have been completed by 239 BCE, less than two decades before the Qin unification. These essays are thus in effect the concluding documents in an extended pre-imperial discourse on the justification for war that begins with Mozi in the fifth 
century BCE. Moreover, the significance of the Annals is more than academic. The compendium was prepared for presentation to the ruler of Qin, and its theory of just arms is a major theme of the celebratory propaganda promulgated by the victorious Qin empire. ${ }^{1}$ If, as a recent anthology about Chinese debates on war suggests, the moral acceptability of warfare has rarely been a focus of discussion in Chinese history, ${ }^{2}$ the Mozi is a shining exception, and the dispute between the Annals and the Mohists deserves special attention.

\section{Conditions of Just War}

As a preliminary to the discussion of early Chinese justifications for war, it is worth briefly sketching a few basic features of contemporary just war theory. Just war theory has two parts, jus ad bellum ("right to war"), which treats the justification for going to war, and jus in bello ("right in war"), which treats right conduct during war. Early Chinese treatments of the ethics of warfare chiefly address jus ad bellum, but some passages also address jus in bello. Accordingly, most of the discussion in the following sections will focus on the justification for war, with a few remarks also on just conduct during war.

The Western tradition of just war theory is typically traced back to Aristotle (384-322 BCE), Cicero (106-43 BCE), and Augustine (354-430). Aristotle formulated the idea that war requires a just cause, while Cicero specified that war could be conducted only by a proper authority. To these objective conditions, Augustine added a subjective requirement: a just war must be fought with the right intention. ${ }^{3}$ A pivotal figure in the development of the tradition was Thomas Aquinas (1225-1274), who synthesized these and other ideas into a systematic doctrine of just war, incorporating the idea of proportionality of means to the ends and introducing the doctrine of double effect. ${ }^{4}$

Just war theorists today typically propose six criteria for jus ad bellum that must jointly be satisfied to justify going to war. ${ }^{5}$ Whether or not these criteria ultimately yield an adequate account of the justification for warfare, they offer a plausible baseline against which to consider early Chinese views on just war.

1. Just cause. War can be made only for a good reason, such as resistance to aggression.

2. Right intention. The actual motivation for the war must be a just cause.

3. Proper authority. Those launching a war must have the legitimate political authority to do so.

4. Probable success. The war must have a good chance of achieving its aims.

5. Last resort. All feasible peaceful alternatives to war, such as diplomacy, must first be exhausted.

6. Proportionality. The expected goods the war will bring about must outweigh the harms it will cause for all affected.

As to jus in bello, theories today commonly require that armed forces (1) must not target the innocent, except in certain extreme cases, (2) must use only force proportional to their justified ends, (3) must treat captives humanely, and (4) must not employ illicit means or weapons, such as genocide, rape, destruction of people's livelihood, or chemical and biological weapons.

As we will see, the core books of the Mozi — which predate Aristotle-clearly allude to rough versions of at least the first four of the criteria for jus ad bellum. Arguably, other Mohist writings imply versions of the last two as well. Competing views in texts such as the Xunzi and The Annals of Lü Buwei focus mainly on just 
cause and right intention, with some attention to proportionality. Regarding jus in bello, on the other hand, the Mozi offers only scattered remarks, while the Xunzi, the Annals, and other texts clearly stipulate that non-combatants should be spared, captives treated humanely, and mass destruction of resources and livelihood avoided.

\section{The Mozi on War}

The Mohists were renowned for their strenuous opposition to military aggression. "All Under Heaven," a Han dynasty retrospective of Warring States thought included in the Zhuangzi 莊子, says that Mozi “cared universally, benefited all-inclusively, and rejected fighting" (33/18). ${ }^{6}$ A story in the Mozi depicts Mozi walking ten days and nights to reach the powerful southern state of $\mathrm{Chu}$ in time to dissuade its king from attacking the small central state of Song.

Speeches reported in the Zuo Zhuan 左傳 commentary on the Spring and Autumn 春秋, an early Chinese historical record, describe as just such motives for war as defending a small state from aggression or punishing criminal behavior. ${ }^{7}$ However, these speeches present no detailed or explicit account of just war, and they may reflect the views of the Warring-States-era compilers of the commentary, not those of the much earlier historical figures it depicts. The Mozi is the earliest text in the Chinese tradition - and perhaps in any philosophical tradition - to address the ethics of war in detail and to articulate a clear stance on what forms of warfare are legitimate.

The unifying basis for discussions of warfare in the Mozi is the text's consequentialist ethical theory. Mozi and his followers held that what is right is determined by what "promotes the benefit of all under heaven and eliminates harm to all under heaven" (16/1). "Benefit," as they understand it, comprises material wealth, a flourishing population, and social order (25/5). Order ( $z h i$ 治) refers to the absence of evils such as violence, crime, exploitation, oppression, and harassment, the presence of social goods such as harmony, cooperation, and charity, and the exercise of relational virtues, such as loyalty and filiality. The universal qualifier "all under heaven" in Mohist formulations of ethical norms is crucial: in evaluating practices and courses of action, we must consider the benefits and harms to everyone affected, not only ourselves. On balance, if we consider the consequences for both sides of a conflict, war almost always wastes wealth, reduces population, and disrupts social order. Therefore, according to Mohist ethics, war is nearly always wrong.

Mohist writings distinguish three kinds of wars: defensive wars (shou 守), punitive wars ( $z h u$ 誅), and aggressive wars (gong 攻). ${ }^{9}$ Defensive wars the Mohists take to be justified when unavoidable. Punitive wars they consider justified in special circumstances, in which demanding criteria are fulfilled. Aggressive wars they consider unjustified without exception. Unlike many anti-war activists, however, the Mohists themselves were keen, expert participants in military affairs, who considered a robust defense force a cornerstone of a state's political and economic strength. Since a state may be forced to engage in defensive warfare and possibly also punitive warfare, they advocated maintaining a high level of military readiness and devoting due attention to city fortifications. A summary of Mohist political and economic views in a late stratum of the Mozi lists among a state's seven most serious worries the inability to defend its city walls and moats, the ruler's failure to make adequate defense preparations, and the failure of neighboring states to come to its assistance against an aggressor (5/1-4). A passage from the Mohist "Dialogues"-four books 
presenting anecdotes and conversations involving Mozi, some presumably fictionaldepicts Mozi chastising the minister of a small state for wasting money on luxuries rather than strengthening his defense force (47/36-40). In the Mohists' historical and political milieu, a prerequisite for promoting the benefit of all was the ability to defend one's own state and to join in interstate defense alliances. Indeed, some Mohists formed specialized militias that were renowned for their prowess in siege fortifications and defensive warfare. (Portions of their technical manuals are preserved in the Mozi.) The Mohists' reputation as defense experts appears to have provided diplomatic leverage to help dissuade potential aggressors from launching unjust wars.

\subsection{Defensive War}

For the Mohists, a justified state policy must promote the benefit of all and eliminate harm to all. Presumably, then, they consider defensive war justified insofar as it promotes benefit or reduces harm, at least for the community under attack. Of course, defensive war may not always promote benefit or reduce harm, compared with letting one's state be peacefully absorbed by an aggressor. Any war is likely to waste lives and resources. A failed defensive war might provoke harmful reprisals that are worse than the consequences of immediate surrender. If the costs of defensive warfare are too high, compared with surrendering one's state without resistance, Mohist ethical theory should justify surrender. ${ }^{10}$ However, the Mohists depict the consequences of invasion in their day as horrific: a conqueror might pillage or destroy all of the defeated state's resources and execute or enslave its people.

Today the rulers of the great states say, without scruples, "Dwelling in a great state without attacking small states, in what way am I great?" So they muster their soldiers and arrange their teams of boats and chariots to attack an innocent state. They enter its borders, mow down its crops, fell its trees, raze its city walls and use them to fill in its moats, burn its ancestral temples, and seize and kill its livestock. People who resist are beheaded; those who do not are brought back in chains, the men to be drivers, grooms, and laborers, the women to thresh grain. (28/46-50, cf. 19/10-14)

For a state under attack, perhaps defensive warfare, even with the risk of defeat, would generally have had better expected consequences than peaceful surrender.

Defensive war for the Mohists includes not only self-defense but the defense of other states, specifically allies and "innocent" (wu zui 無罪) small states targeted by belligerent larger states (19/12). Good statesmanship requires cordial, mutually beneficial relations with other states, such that all are prepared to come to each other's defense (19/57, 5/1-2). Through orderly domestic government and mutually beneficial diplomatic relations, states establish themselves as innocent and thus deserving of defense assistance.

One passage in the Mohist "Dialogues" suggests that diplomacy and even political submission to a powerful aggressor may sometimes be preferable to defensive war. Fearful of an attack by the powerful state of Qi, the Lord of Lu asks Mozi what can be done to save his state (49/1-4). Mozi cites the examples of the four sage-kings, who by teaching loyalty and practicing justice rose from small fiefdoms to rule the world, and the four tyrants, who through enmity and violence lost their empires. Disaster can be avoided, he suggests, by "revering Heaven and serving the 
ghosts above, caring for and benefiting the people below, and collecting furs and coin, making yourself humble in speech, paying respects to the neighboring feudal lords and leading the state to serve Qi." These remarks suggest two concurrent courses of diplomacy. Lu should develop friendly ties with neighboring states, so that they support its defense, while diplomatically subordinating itself to Qi if needed to avoid war. The passage hints that the Mohists regarded diplomacy as preferable to defensive war even when the cost might be vassalage to a larger state. Their reasoning was probably that whatever harm might come from diplomatic subjugation would be less than the harm of war, or at least a mismatched war with little likelihood of success. The passage may be applying an implicit criterion of probable success to argue against war, or it may reflect the view that defensive war is justified only as a last resort, when no peaceful diplomatic alternative is available.

The story of Mozi's dissuading Chu from attacking Song illustrates another aspect of Mohist peace activism and diplomacy. While a company of three hundred Mohists prepares to defend Song with force if needed, Mozi travels to Chu to persuade the King to call off the attack. Mozi first tries rhetoric:

"Suppose there were a person here who set aside his elegant carriage, as his neighbor had a broken cart and he wanted to steal it. He set aside his embroidered finery, as his neighbor had a short jacket and he wanted to steal it. He set aside his grain and meat, as his neighbor had some chaff and dregs and he wanted to steal them. What kind of person would this be?"

The King said, "Surely he would be a kleptomaniac."

Mozi said, "The territory of Chu is five thousand square $l i$; the territory of Song is five hundred square $l i$. This is like the contrast between an elegant carriage and a broken cart. Chu has Yun Meng; rhinoceroses and deer fill it. The fish, tortoises, and crocodiles in the Yangzi and the Han Rivers are the richest in the world. What Song lacks are even pheasants, rabbits, and foxes. This is like the contrast between grain and meat and dregs and husks. Chu has tall pines, catalpa, camphor, and oak. Song has no tall trees. This is like the contrast between embroidered finery and a short jacket. Your subject takes these three aspects of attacking Song to show that doing so would be conduct of the same kind as the kleptomaniac's. I see the great King will surely injure justice to no gain." $(50 / 8-13)$

The King concedes but says he must take Song nevertheless, because Gongshu Ban, his military engineer, has already built the siege engines. Mozi then uses his belt and a stick as models to show how his militia's defensive techniques can effectively counter all nine of Gongshu's methods of attack. Seeing this, the King cancels the invasion. The story implies that the Mohists put diplomacy before defensive war but found the threat of a formidable defense pivotal to achieving peace through diplomacy.

\subsection{Aggressive War}

Aggressive war for the Mohists is always unjustified. A war of aggression, as they understand it, is an offensive war against a state that is innocent (19/12). Mohist texts do not directly spell out criteria for a state to be innocent, but several conditions can be inferred from their stories about justified punitive war. In at least some cases, they 
consider punitive war justified when a state or its leader has fallen into "great disorder" (19/33), insulted Heaven and the spirits (31/84), attacked other states $(49 / 16)$, or inflicted atrocities on the people (31/89). For a state to qualify as innocent, then, minimally its leaders must be orderly, devout, peaceful toward other states, and benign to their subjects. If a state is innocent, in this sense, there can be no morally sound justification for aggression against it.

The Mohists offer both moral and prudential arguments against wars of aggression. ${ }^{11}$ The moral arguments aim to show that, for various reasons, wars of aggression are morally wrong. The prudential arguments aim to show that such wars are against the interests of the aggressor's own state, since the costs far outweigh the benefits. In Mohist ethics, of course, since the distinction between benefit and harm determines right and wrong, demonstrating that the harms of some action outweigh the benefits is tantamount to showing it is morally wrong. So the prudential arguments also support the conclusion that aggressive war is immoral. One argument combines moral and prudential concerns, contending that even if a ruler wages war for morally admirable ends, aggression is a poor means of pursuing them.

The moral arguments are presented mainly in three of the Mohist "triads": the first and third "Condemning Aggression" essays (Mozi Books 17 and 19) and the third "Heaven's Intent" essay (Book 28). ${ }^{12}$ The shared theme of these arguments is that aggressive warfare fails to meet the basic moral standard of promoting the benefit of all. The first moral argument appears in the earliest "Condemning Aggression" essay $(17 / 1-7)$.

Now suppose someone entered another's orchard and stole the peaches and plums. If the community heard about it, they would condemn it. If the superiors who administer the government caught him, they would punish him. Why is this? Because he injured another to benefit himself. When it comes to carrying off another's dogs, hogs, chickens, and pigs, the unjustness is even greater than entering another's orchard and stealing the peaches and plums. What is the reason for this? Because the more someone injures another, the more malevolent he is and the more serious the crime. When it comes to entering someone's stable and taking the person's horses and oxen, this is even more malevolent and unjust than carrying off another's dogs, hogs, chickens, and pigs. What is the reason for this? Because it injures another more. If it injures another more, the more malevolent it is and the more serious the crime. When it comes to killing an innocent person, stripping him of his clothes and furs, and taking his spear and sword, this is even more unjust than entering another's stable and taking the person's horses and oxen. What is the reason for this? Because it injures another more. If it injures another more, the more malevolent it is and the more serious the crime. In these cases, the gentlemen of the world all know to condemn these acts and call them unjust. Now when it comes to the great matter of attacking another state, they don't know to condemn it, but rather praise it and call it just. Can this be called knowing the difference between just and unjust? (17/1-7)

Example by example, the text builds to the analogical conclusion that unprovoked military aggression is unjust in exactly the same way that theft and murder are: "it injures another to benefit oneself." Indeed, war is far worse than these crimes, for the same reason that murder is worse than theft: "It injures another more. If it injures another more, the more malevolent it is and the more serious the crime." To the 
Mohists, unjust war is a crime of the same kind as theft, robbery, and murder, only on a larger scale. "The gentlemen of the world" fail to see this, however. They are "confused" in distinguishing the just from the unjust (17/14) and thus see military conquest as a proud achievement to be memorialized for later generations, rather than a crime $(17 / 10){ }^{13}$

The third "Heaven's Intent" essay makes the underlying inconsistency explicit. In governing their states, "kings, dukes, and great men" all punish murder and theft just as the ancient sage-kings did. Yet they invade, attack, and annex other states, a crime amounting to "thousands and tens of thousands" of murders and thefts (28/61-64). Their own governments prohibit killing people, yet they deem it just to kill as many people of a neighboring state as possible. How is this different, the text asks, from calling a small amount of black "black" but a large amount "white" (28/66-67)?

The third "Condemning Aggression" essay presents a more elaborate moral argument (19/15-19). Everyone knows that what is good or moral is what benefits all denizens of the cosmos: Heaven, the ghosts, and people (19/3-4). But wars of aggression do not benefit Heaven. Just the opposite: they employ some of Heaven's people to massacre others, while dispossessing spirits from their shrines, overthrowing the altars of soil and grain, and slaughtering the sacrificial animals. They fail too to benefit the ghosts and spirits, since they result in the death or scattering of their worshippers. Nor do they benefit people: obviously, those who die do not benefit, and much of the survivors' material resources are wasted. Since such wars are harmful at all three levels, they are morally wrong.

The prudential argument that wars of aggression are against the aggressor's own interest is the main theme of the second "Condemning Aggression" essay and reappears in the third. The argument amounts to a litany of the costs and harms of war for the aggressor. War interrupts planting or harvesting. It wastes innumerable quantities of weapons, military supplies, vehicles, and livestock. People die because of harsh weather, insufficient food, illness, and injury in battle. The spirits suffer because of the death of their worshippers. Warlike rulers might rejoin that these costs are offset by the fame and plunder that victory brings (18/10). The Mohist reply is that the spoils of war are simply never enough to make up for the costs:

Calculate what they win for themselves, and there is nothing they can use. Calculate what they gain, and on the contrary it is not as much as what they lose. Now attacking a city of three $l i$ with an outer wall of seven $l i$, if one could attack this without using weapons and capture it without killing, that would be one thing. But only by killing people - whether many, which must be counted in the tens of thousands, or few, which must be counted in the thousands - can a city of three $l i$ with an outer wall of seven $l i$ be captured. Now states of ten thousand chariots have empty towns in the thousands that can be entered without conquest and wilds in the ten thousands that can be developed without conquest. If so, then land is what they have in surplus, while population is what is insufficient. Now to maximize the deaths of the population while aggravating the troubles of superiors and subordinates in order to fight for an empty city, this is to discard what is insufficient while valuing what is in surplus. $(18 / 10-15)$ 
No warlike state lacks land, yet they waste what they need - human lives - in pursuit of what they possess in abundance - villages, cities, and farmland. Governing in this way is contrary to the proper ends of the state $(18 / 15)$.

Opponents might object that some states have indeed benefited from wars of conquest. Chu and Yue in the south and Qi and Jin in the north all increased their territory and population through aggressive wars. The Mohist reply is that a handful of successes among a myriad failures shows that aggression fails to conform to the morally right Way (dao 道), just as a doctor who treats many patients but heals only a few fails to genuinely treat disease:

Although four or five states benefited from this, we still declare it not practicing the Way. To give an analogy, it is like a doctor medicating people who have diseases. Suppose there were a doctor who brought together for treatment all the diseased people in the world and medicated them. A myriad people taking this, if four or five people treated benefit from it, we still declare it not practicing medicine. So filial sons do not give it to their parents and loyal subjects do not give it to their ruler. (18/18-20)

The text goes on to cite numerous examples of states that were extinguished because of their own or others' aggression. For the Mohists, the Way refers to norms that everyone can practice regularly and consistently with beneficial results for all. So the fact that only four or five exceptional states among a myriad have benefited from aggression shows that aggressive war is not the Way.

To these arguments, warlike rulers might rejoin that the Mohists' list of states that destroyed themselves by undertaking wars of aggression shows only that the states' leaders were incompetent, or "unable to muster and employ their multitudes" (18/26-27). With competent leadership, aggressive war can be profitable. In rebuttal, the Mozi cites historical examples of brilliant generals whose military adventures were initially successful but eventually brought reprisals, defeat, and ignominious death (18/27-39). Even for leaders as talented as these, aggressive war is unlikely to yield long-term profit and security.

A further argument against aggression combines prudential and moral concerns. The third "Condemning Aggression" essay considers the view that aggression might be justified if the aggressor's motive is not material gain but "to establish a reputation for justice across the world and to attract the various lords with virtue" (19/55). For prudential, self-interested reasons, the aggressor aims to achieve an admirable moral status and considers wars of conquest a reliable way to do so. A reputation for justice and virtue is a laudable ambition, the Mohists agree, but aggressive war is a misguided means of pursuing it. To achieve this aim, a ruler should instead conduct diplomatic relations in good faith, distribute military and economic aid generously to other states, and govern morally and effectively in his own state - thus befriending other states while strengthening his own. In this way, he would bring innumerable benefits to all and have "no match in all the world" (19/5561). Wars of aggression are unjustified even if driven by praiseworthy motives.

\subsection{Punitive War}

The third "Condemning Aggression" essay, chronologically the latest of the three, raises an important objection to Mohist criticisms of aggressive war. According to historical accounts widely accepted in the Mohists' era, several of the sage-kings they 
admired as moral paragons carried out successful offensive military campaigns. Yu suppressed the Miao tribes; Tang overthrew the tyrant Jie of the Xia dynasty, and $\mathrm{Wu}$ toppled the tyrant Zhou of the Shang dynasty. If wars of aggression are harmful and unjust, as the Mohists contend, why did the sage-kings launch these wars? The Mohist reply is that these offensive campaigns were not wars of aggression (gong). They were punitive missions $(z h u)(19 / 32-33)$, a type of offensive warfare that overlaps partly with what we might call humanitarian intervention. The Mohists allow that in the case of punitive missions, offensive war may sometimes be justified.

The treatment of punitive war in the Mozi is a rich, early example of a justification for offensive warfare that has been neglected as a source of the pre-Han concept of just arms (yi bing). ${ }^{14}$ Although the Mozi itself does not use the phrase "just arms (yi bing)," it is the earliest text to articulate the concept of punitive war $(z h u)$, which is the basis for the later notion of just arms. In the Mozi, the distinction between aggressive and punitive war is drawn explicitly only in the passage defending the wars of the sage-kings. However, the theme of punitive war appears repeatedly. Several passages in the triads claim that a state which follows Mohist policies will be "strong when entering to defend (shou) and powerful when emerging to punish $(z h u) . " 15$ Moreover, Mohist moral arguments against aggressive war repeatedly draw analogies between wars of aggression and theft, robbery, and murder. As Van Els points out, ${ }^{16}$ although the moral arguments do not mention punitive warfare, the crime analogy implies that such wars might be justified, since the Mohists expressly endorse punishment for lesser crimes.

To vindicate the sage-kings' supposedly punitive wars, the Mozi presents a series of elaborate stories, replete with portents from Heaven and visits from spirit emissaries. Although the stories amount mainly to a concocted apology for these wars, they jointly illustrate a series of conditions under which the Mohist writers consider punitive war justified. Intriguingly, these implied conditions overlap significantly with mainstream views today of the conditions for jus ad bellum.

The first and most prominent condition justifying these punitive wars is that all were purportedly conducted with divine sanction. ${ }^{17}$ According to legend, Heaven expressed its condemnation of the targets of the punitive missions through miraculous portents, including freak weather, crop failure, midnight sun, rains of blood and flesh, screeching ghosts and animals, and fantastic creatures, such as a giant bird with a human head. Even more important, Heaven dispatched spirit emissaries to publicly authorize the sage-kings' campaigns. Since the Mohists apparently expect Heaven's mandate to be signalled by such publicly observable miracles, the criterion of divine sanction turns out to be extremely - in practice, impossibly - demanding. ${ }^{18}$ Indeed, one purpose of the stories may be to rule out claims to Heaven's mandate through private revelation: if Heaven does sanction an invasion, it will alert many witnesses.

Heaven's sanction does not correspond directly to any condition in just war theory today. However, in the Mohists' philosophical and religious context, the mandate of Heaven can be interpreted as fulfilling the condition of proper authority for punitive warfare. One Mozi passage draws an explicit analogy between Heaven's punishment of those who launch aggressive wars and a sovereign's punishment of criminality within a state (49/12-16). The implication is that the only authority that can legitimately initiate a punitive mission is Heaven itself. We will return to this important point in Section 6.

Beyond Heaven's role as a proper authority for launching punitive wars, the reasons the Mohists give for Heaven's sanctioning punitive missions correspond to several modern criteria for jus ad bellum. First, Heaven does not sanction punitive 
wars capriciously or arbitrarily. It does so for good reasons, which correspond to the condition of just cause in contemporary just war theory. In each of the Mohists' examples, the punished state had purportedly fallen into disorder. The most detailed accounts of this disorder report that the tyrants Jie and Zhou blasphemed Heaven and the spirits and massacred their own people (31/83-84, 31/89). Zhou is accused of atrocities such as abandoning the elderly, murdering children, torturing the innocent, and slicing open the wombs of pregnant women (31/89). Punitive missions are thus undertaken to put an end to chaos and atrocities and restore peace and order.

Second, a punitive war must be waged with good intention. Specifically, the Mohists explain, it should be waged not for self-interest, but, as in Yu's campaign against the Miao, to promote the benefit of all:

Yu's subjugation of the Miao was not to seek to expand his wealth and status, obtain blessings and rewards, or please his ears and eyes. It was to seek to promote the benefit of all the world and eliminate harm to all the world. $(16 / 54-55)$

Each of the purportedly justified punitive wars was fought to secure peace and stability. This condition corresponds roughly to the condition of right intention in Western just war theory.

Third, the sage-kings had good reason to believe their punitive wars would succeed, as the spirits who commanded the attacks expressly guaranteed success.

Shortly a spirit came to announce, "The virtue of Xia is in great disorder. Go to attack them. I will surely cause you to have a great victory over them." $(19 / 40)$

A crimson bird holding a jade sceptre landed by the Zhou shrine and said, "Heaven mandates King Wen of Zhou to invade Yin and possess its state."...King Wu ascended the throne and in a dream saw three spirits, who said, "We have immersed Zhou of Yin in the power of wine. Go to attack him. We will surely cause you to have a great victory over him." (19/44-46)

Although today we might doubt whether purported announcements from spirits are good grounds for expecting a military victory, these features of the stories correspond to the condition of probable success in modern just war theory.

Despite its fanciful, mythical trappings, then, the Mohist doctrine of punitive war overlaps four of the six criteria for jus ad bellum typically proposed in just war theory today: just cause, right intention, proper authority, and probable success. Moreover, as we will see, further remarks in the Mozi hint at the two remaining criteria, last resort and proportionality.

\section{Justification of War in the Pre-Han Literature}

In treating defensive, aggressive, and punitive war, the Mozi touches on many of the positions and arguments concerning warfare treated in other early Chinese philosophical and military texts. This section surveys these positions and arguments to fill in the background to the debate between the Annals and the Mozi.

\subsection{Pacifism and Self-Defense in Daoist Texts}


The Mohists were not the most radical critics of warfare among pre-Han thinkers. A few middle to late Warring States figures are reported to have rejected war entirely, advocating wholesale pacifism, or "laying down arms." The Zhuangzi "All Under Heaven" essay reports that the anti-war activists Song Xing and Yin Wen "prohibited aggression and put arms to rest (qin bing 寢兵) to save the world from war” (33/41). The Annals (18/7) similarly reports that Gongsun Long urged King Zhao of Yan to lay down arms (yan bing 偃兵). ${ }^{19}$ Unfortunately, no detailed arguments for these pacifist views have been preserved. As we will see below, the Annals is expressly concerned to refute the doctrine of laying down arms, but it does not expound proponents' case for the doctrine.

Other texts, chiefly those in the Daoist tradition, advocate maintaining arms but using them mainly in self-defense, as a last resort. Avoiding conflict (zheng 爭) is among the key themes of the Daodejing 道德經. ${ }^{20}$ One passage states that those who assist a ruler by means of the Way do not coerce the world with arms (30). War is an ineffective means of pursuing one's aims, to be used only as a last resort: "Arms are instruments of ill omen, not the instruments of a gentleman. Only when there is no choice does one use them. ... As to one who enjoys killing others, he cannot fulfill his intent in the world" (31). The wise avoid taking the initiative in resorting to arms but only respond: "In employing arms, there is a saying: I dare not be the host but am the guest, dare not advance an inch but retreat a foot" (69). Ideally, according to some sections of the Daodejing, people will live in small states, where they possess arms and armor but have no occasion to display them (80). The implication throughout is that war is justified mainly in self-defense. ${ }^{21}$

Several stories in the Zhuangzi criticize military aggression. In one, the sageking Yao announces his nagging ambition to conquer several smaller states only to have Shun dismiss this end as unbecoming. Yao should focus instead on developing his virtuosity or power of character (de 德), which can shine more brightly than the sun (2/62-64). Military aggression is beneath a worthy ruler; a more effective approach to influencing others is simply to cultivate ethical charisma or virtuosity. Another passage alludes to the same tale, criticizing Yao and also $\mathrm{Yu}$ for invading several smaller states, reducing their lands to wastes and ghosts, and executing their rulers. "Their employment of arms did not cease, their seeking material advantage never stopped" (4/13-14). The stance of this passage contrasts sharply with that of the Mozi, since $\mathrm{Yu}$ is among the sage-kings whose punitive missions the Mohists declare legitimate. In a third story, a Daoist worthy offers a parable to convince King Ying of Wei that attacking a former ally for violating a treaty would be barbaric and pointless (25/20-31).

Another Zhuangzi passage also rejects pacifism, however. The Daoist teacher $\mathrm{Xu}$ Wugui criticizes Marquis Wu's proposal to lay down arms (yan bing) on behalf of justice or right ( $y i$ 義). Laying down arms, Xu contends, is actually a root cause of war, as any forced attempt to achieve an admirable end is likely to have complex, partly negative consequences. The Marquis should neither embrace pacifism nor amass troops and seek to defeat others, for it is unclear what is good in war or in what victory lies. Instead, he should simply respond to the actual conditions he encounters, seeking only to spare his people from death (24/19-25). The implication is that both pacifism and aggression are short-sighted, while self-defense is generally appropriate when unavoidable. 


\section{2 "Just Arms" in Realist and Military Texts}

Some so-called "Legalist" or "Realist" texts advocate military aggression provided a campaign is likely to profit the ruler of the state. For these texts, the moral justification for war is irrelevant. The Book of Lord Shang 商君書, for instance, assumes as a basic premise that agriculture and war are the means by which a state flourishes $(4 / 2 / 21){ }^{22}$ War is treated as essential to the health of the state $(13 / 17 / 16)$. One wins reputation and territory and becomes a king through victory in battle $(18 / 23 / 11)$. Indeed, a true king is one who can make his people take pleasure in battle $(18 / 23 / 15)$.

By contrast, some passages in the Guanzi 管子 distinguish justified from unjustified war. The pattern of the virtuous subjugating the unworthy has existed since ancient times, so it is legitimate to punish a state that has strayed from the Way. ${ }^{23}$ A robust military force is essential to the reputation of the sovereign and the security of the state, as it is the means by which one punishes violence abroad and prohibits wickedness at home. ${ }^{24}$

Many early military texts address the moral grounds for warfare, at least in passing. The most famous such text, the Sunzi Bingfa 孫子兵法, focuses on strategy and tactics without treating the justification of war. However, another important military text, the Sima Fa 司馬法, addresses the issue in its opening lines: "If one kills people to bring peace to people, killing them is permissible; if one attacks a state out of care for its people, attacking it is permissible. If one stops war by means of war, although it is war, it is permissible" (D1/45/3-4). ${ }^{25}$ Like the Mozi, the text draws a parallel between criminal punishment within the state and military campaigns to punish immorality, a conceptual connection we will explore further below (D1/45/18). It also goes beyond the question of jus ad bellum (the right to engage in war) to touch on jus in bello (right conduct in war). An invading force sent to punish the rulers of an offending state are not to do violence to its gods, hunt its game, destroy earthworks or buildings, cut forests, or seize livestock, grain, or tools. They are not to harm the elderly or young or even to treat adults as hostile unless attacked. Wounded enemies are to be treated and returned (D1/45/23-25).

Another important early military text, the $W u z i$ 吳子, identifies five types of warfare, of which the first is "just arms," which lies in "ending violence and rescuing from disorder" $(\mathrm{C} 1 / 36 / 30) .{ }^{26}$ The text emphasizes that military action must be grounded in the virtues of the Way, justice, ritual propriety, and benevolence. These virtues explain why the people of Xia were pleased when the sage-king Tang deposed their tyrannical ruler Jie and the people of Yin did not condemn King Wu for conquering the despot Zhou (C1/36/21-22). The implication is that only just war is permissible. $^{27}$

Other, less well-known military texts reinforce the conception of a justified war as a morally motivated punitive mission against a violent or tyrannical regime. The Three Strategies 三略 contends that the sage-king employs arms not because he takes pleasure in doing so but to punish violence and penalize disorder, using the just to punish the unjust. ${ }^{28}$ The Six Secret Teachings 六鞱 states that war must be undertaken for a just cause, as this motivates the masses to defeat the enemy. ${ }^{29}$ The Weiliaozi 尉繚子 acknowledges that, as the Daodejing states, arms are instruments of ill omen. Hence it urges that, in conquering the violent and disorderly, a king's action must be rooted in benevolence and justice (B23/33/17). ${ }^{30}$ Armies must not attack cities that have committed no transgressions or people who have committed no 
crimes. Killing others' fathers or brothers, seizing their wealth and goods, or enslaving their children is robbery. Armies are to be used only to punish disorder and end immorality (B8/22/17-18).

\subsection{Punitive Warfare in Early Confucian Texts}

As the Mozi and the military texts show, by the late fourth to the early third century $\mathrm{BCE}$, the notion of a punitive mission to remove a vicious ruler had become the prevailing view of justified offensive warfare, rejected only in some Daoist texts. This trend is confirmed by the three major pre-Han Confucian anthologies. Hints of this view of punitive war can be found in the Analects of Confucius, the earliest parts of which date from the middle of the fifth century BCE. The view is applied in the late fourth-century Mengzi and stated explicitly in the third-century Xunzi.

One passage in the Analects 論語 includes arms (bing 兵) among the three keys to government but ranks them below the other two, the people's trust and an adequate food supply (12.7). ${ }^{31}$ This lower priority reflects the text's general distaste for violence and coercion. In domestic government, for instance, the Analects strongly urges rule through virtuous example and moral charisma, rather than by killing or punishment $(12.19,2.3)$. A passage in a late stratum of the text denounces a plan by a branch of the Lu royal family to attack a Lu dependency, arguing that military aggression is an inappropriate way to make distant subjects submit. A better approach is for leaders to cultivate virtue and attract subjects through the force of moral charisma (16.1). The text thus rejects warfare aimed at intimidation or subjugation. Elsewhere it seems to endorse punitive warfare, however. After a nobleman in the state of Qi murders its sovereign, Confucius urges the ruler of Lu to dispatch troops to punish him (14.21).

Passages in the Mengzi 孟子 endorse defensive war, provided the ruler has won his subjects' loyalty through benevolent government, and support punitive war against states that have mistreated their people (1.5). ${ }^{32}$ When King Xuan of Qi conquers Yan to punish its ruler for cruelty to his subjects, Mencius approves of the punitive invasion. However, he chastises Xuan for killing and imprisoning the people of Yan, destroying their temples, stealing their precious vessels, and failing to practice benevolent government (2.10-2.11). He offers a populist criterion for rightful punitive war: invasion or annexation is legitimate if the people of the conquered state welcome the invading army for rescuing them from a vicious ruler and are pleased to be annexed. Indeed, it is like the fall of "timely rain" (2.10), an analogy later adopted in both Xunzi and the Annals. The Mohists offer no such populist standard, probably because they assume Heaven itself will indicate when punitive war is justified.

Mencius extends the Confucian view of rule and subjugation by moral charisma into the doctrine that the benevolent ruler has no match or enemy $(1.5,7.7$, $14.3,14.4)$. The morally virtuous ruler can conquer misgoverned states unopposed, since their people will perceive his virtue and the rightness of his cause and abandon their tyrannical rulers to welcome him. Mencius is so convinced that such encounters will be effectively bloodless that he dismisses historical reports to the contrary as apocryphal (14.3). ${ }^{33}$ At the same time, however, the Mengzi raises the problem of proper authority for punitive war. ${ }^{34}$ One passage declares that punitive missions can be carried out only by superiors against subordinates (14.2): a king can punish the lord of a city, for instance, but states that are equals lack the authority to punish each other. Only an "official of Heaven" — not the King of Qi — could have had the proper 
authority to invade and punish Yan, Mencius claims retrospectively (4.8). Perhaps justified punitive war indeed requires divine sanction, as the Mohists hold.

The third major anthology of pre-Han Confucian thought, the third-century BCE Xunzi 荀子, explicitly addresses the justification for war. A student points out that Xunzi claims the moral values of benevolence and justice are the basis for military affairs. Yet "those who are benevolent care about others, those who are just conform to orderly patterns" (15/66-67). ${ }^{35}$ Why take up arms, since aggression seems contrary to these moral ideals? The answer, the student suggests, is that those who launch wars do so simply to fight for the spoils (15/67). Xunzi's response is that on the contrary, the benevolent and the just resort to arms precisely because they possess these moral virtues:

The benevolent care about others. They care about others and so detest it when someone harms them. The just conform to orderly patterns. They conform to orderly patterns and so detest it when someone disorders them. Taking up arms is the means of ending violence and eliminating harm, not a matter of fighting to seize plunder. So the army of a benevolent ruler, wherever it is, it has an effect like a spirit; wherever it passes, it brings about transformation. It is like the fall of timely rain-no one does not rejoice. (15/67-69)

The army of a benevolent, just ruler prevails less by its strength of arms than by the power of its moral virtue or charisma. ${ }^{36}$ The military exploits of the "four emperors and two kings"- Yao, Shun, Yu, and Tang, along with Kings Wen and $\mathrm{Wu}$ - all were cases of "marching through the world with armies of benevolence and justice."

So those nearby found [these sage-kings'] goodness dear, while those far off admired their virtue. The soldiers did not bloody their blades, yet those far and near came to submit. $(15 / 70-71)$

Such armies follow strict standards for the conduct of war (jus in bello). A true king engages only in punitive missions (zhu) and not in warfare (zhan 戰). Punitive missions target only those who have brought disorder to the common people, not the people themselves. The true king does not attack a city that is well defended or troops who resist. He does not massacre the inhabitants of cities, move troops covertly, or keep his forces in the field long. His troops do not kill the old or weak, destroy crops, or capture those who submit or flee. So the people of disorderly states wish for his arrival. $^{37}$

Both Mencius and Xunzi, then, compare a virtuous king's punitive invasion of a misgoverned state to the felicitous arrival of seasonable rain. Both contend that such an invasion will incur little bloodshed and will be welcomed by the people of the badly ruled state, who the invading force must leave unharmed. Both see virtue itself as a source of power, a "force multiplier" that ensures a just army will prevail. ${ }^{38}$ Neither text provides concrete criteria to identify misruled states, beyond claiming they are disorderly and fail to follow the Way. Perhaps the most specific criterion is Xunzi's remark that if the ruler and subjects of a state delight in each other, the king congratulates them rather than invading (15/65). The Mencius implies that some form of divine mandate might be required to justify punitive war. By comparison, the Xunzi elicits the worry that the notion of punitive war could degenerate from a commitment to rescuing victims of cruelty into a license for a powerful ruler to seize any state whose leadership he deems less virtuous than his own. ${ }^{39}$ 


\section{The Annals on Just Arms}

Outside of the Mozi, the richest treatment of the ethics of warfare in the pre-Han literature appears in The Annals of Lü Buwei, which contains several short essays devoted to rejecting pacifism, rebutting the view that only defensive warfare can be justified, and presenting an account of just arms.

The discussion of pacifism argues that the ancient sage-kings recognized the notion of just arms (yi bing) but not the pacifist doctrine of laying down arms (yan bing). ${ }^{40}$ Arms cannot be laid to rest, as they are an ancient, inevitable part of human life and the root of political authority. The first political authorities were chiefs who won their status in combat. When chiefs proved unable to govern, lords were established, and when lords proved unable to govern, the emperor was established. But the authority of the emperor ultimately issues from the combat that established the chiefs. Since combat has always been part of life and underwrites political authority, the essay concludes, there can be such a thing as just arms but no general renunciation of arms. ${ }^{41}$

The text draws an analogy between using a whip to prevent misbehavior by children in the home, criminal punishment to prevent offenses by people in the state, and punitive missions to prevent violence between lords of states in the empire. Just as a family cannot renounce discipline in child-rearing and a state cannot renounce criminal justice, punitive invasions cannot be renounced. It would be perverse to ban all food because of a few deaths from food poisoning or all boats because of a few deaths in boating accidents. Similarly, it would be perverse for all to lay down arms because a few lost their states in military adventures. Arms are like water or fire: they may be used more or less skillfully, leading to positive or negative results, but they cannot be abandoned. If an army is genuinely just, it is used to punish tyrants and relieve suffering and thus pleases the people.

The next pair of essays rebut the stance that only defensive warfare can be justified and offensive warfare must be rejected (7/3.1-7/4.2). "In the present age, many scholars...condemn offensive warfare while advocating rescue and defense" (7/3.2). The "many scholars" presumably are mainly the Mohists. As we will see, the view the Annals criticizes is not that of the Mozi, but it could easily have been confused with the Mohist view.

According to the Annals, the view that only defensive war can be justified is mistaken for two reasons. First, offensive and defensive warfare refer to one and the same activity; no fixed distinction can be drawn by which one and not the other can be rejected. The text claims that offensive warfare is used only to attack those who lack the Way and to punish the unjust. Attacking and punishing those who are in the wrong greatly benefits the people, so by a consequentialist ethics such as the Mohists', such offensive warfare is right. Second, if we hold that aggression is always wrong and defense always right, we will end up defending those who lack the Way and rescuing those who are unjust. Moreover, in taking up arms to do so, we will be forced to kill innocent soldiers. These actions are harmful and so are morally wrong. Indeed, committing to defense without first distinguishing between just and unjust recipients of assistance is a serious injustice, since punishing wrongdoers is only right. Hence it is a mistake to advocate or condemn offensive or defensive warfare in general. The only permissible position is to endorse just arms (yi bing) (7/4.2). If a military expedition is just, then either attack or defense is permissible; if it is unjust, neither is. 
Now to urgently adopt rescue and defense without differentiating whether it is just or unjust, there is no injustice greater than this and no harm to the people of the world more extreme than this. So, adopting attack and invasion is impermissible, condemning attack and invasion is impermissible, adopting rescue and defense is impermissible, and condemning rescue and defense is impermissible. Only adopting just arms (yi bing) is permissible. If the use of arms is just, then attack and invasion are indeed permissible and rescue and defense are indeed permissible. If the use of arms is unjust, then attack and invasion are impermissible and rescue and defense are impermissible. (7/4.2)

Another short essay (Annals 7/5.2-5.4) gives guidelines for the conduct of the just army (yi bing), which can be interpreted as an account of just conduct in war (jus in bello). The invading army is not to kill the civilian population, destroy crops, plunder graves, fell trees, burn storehouses, torch houses, or seize livestock. Heralds are dispatched to announce that the army has come to rescue the people by punishing $(z h u)$ their unfit ruler, eliminating enemies of the people, and following the Way of Heaven. Those who aid the ruler are killed, but those who cooperate with the invaders are rewarded. Punishment is dealt only to offenders. The remainder of the populace is to be treated well. Accomplished officials are promoted and given salary increases, orphans and widows receive assistance, elders are shown respect, the state's wealth is distributed amongst the people, and its shrines and temples are restored. These measures aim to ensure that the conquered people glorify the invader's name, delight in his conformity to ritual propriety, and cherish his virtue. The success of a punitive expedition rests less on military might than on moral authority, as reflected by the subjugated people's acceptance of a worthy new ruler. ${ }^{42}$

When a just army arrives, the people of neighboring states come to them like flowing water and the people of punished states look up to them as parents. The farther they march, the greater is the multitude of people they win over. Without the soldiers crossing blades, people submit as if transformed. (7/5.4)

The heralds' announcements spell out the crimes of rulers who lack the Way and thus are legitimate targets of just arms. Allegedly, an unfit ruler is arrogant and decadent, predatory and oppressive, licentious and selfish. He strays from sagely institutions, slanders the former kings, and rejects old canons. He does not follow Heaven and is unkind to the people; he taxes without limit and ceaselessly appropriates the people's wealth. He executes the innocent and rewards the unworthy. These accusations can plausibly be taken as rough conditions for a just punitive invasion.

The Annals thus draws together many key features of the views on just war found in realist, military, and Confucian texts. The text considers the use of arms unfortunate but sometimes necessary, so it rejects wholesale pacifism. It holds that, in addition to self-defense, resorting to arms may be justified to restore order in other states or to punish unfit, cruel, or belligerent rulers. It assumes that punitive war is analogous to criminal punishment of an unfit ruler. The subjects of the targeted state are considered victims of misrule, not perpetrators of violence, so they are to be spared and their livelihood preserved. They are expected to recognize a just conquering army as rescuers and accordingly welcome and assist them. Such a response from the conquered people confirms the justness of the punitive mission and 
supposedly ensures that bloodshed will be minimal. Arguably, the approval of a state's residents might indeed provide good grounds for offensive intervention to depose its unfit leaders. Without rigorous opinion polling, however, it is hard to see how the extent of such approval could be evaluated reliably. A conqueror's own selfserving claim of popular support is hardly a convincing justification for war.

Intriguingly, the Annals, the Mencius, and the Xunzi all assume that the residents of a conquered, misgoverned state have no loyalty to their state, as opposed to its venal leadership, and no concern for the sovereignty of its territory. The writers of these texts never imagine that the subjects of a state might resist invasion because they identify with the state, wish to defend its sovereignty, or resent occupation by foreigners. Indeed, the writers assume that, provided the ruler is indeed corrupt, the attacking army announces its aim to remove him, and residents of the state are unharmed, the residents can have no legitimate objection to the invasion. As these attitudes illustrate, in early Chinese political thought, the concepts of sovereignty and of membership in a polity or nation are at best vague and inchoate, as is the distinction between loyalty to a state and to the particular individuals who happen to govern it.

The Annals' view of just war clearly incorporates features corresponding to just cause and right intention, and arguably it considers probable success as well. However, it raises crucial questions about the authority for punitive war, the justification for war when other alternatives remain, and the proportionality of war as a response to misrule. For the Annals' stance implies that a just punitive attack can be launched against a state without a previous act — or even intention — of aggression against the attacker. ${ }^{43}$ Indeed, the text hardly considers the case of responding to aggression or the threat of aggression against one's own state. The focus is on punitive action against a state that has allegedly harmed its own subjects or others.

\section{Can Offensive War be Justified?}

Although the Annals presents a veiled attack on the Mohists, the two texts' views of just war differ little in principle. As we have seen, the Mozi does not argue that all offensive warfare is wrong or that all defensive warfare is justified. It argues that "unjust" (17/9) offensive warfare against an "innocent" state is wrong, and it considers the sage-kings' punitive missions justified. The elaborate story of Mozi rushing to defend the weak state of Song from $\mathrm{Chu}$, a powerful aggressor, specifies that Song is "innocent" (50/4). The Mohists might agree that defense is unjustified if the victim of aggression is unworthy. When Mozi encourages the Lord of Lu to employ diplomacy to defuse a threat from Qi, he implies that aggression is best prevented by governing one's own state virtuously and building friendly relations with other states (49/1-4). Such measures make a state worthy of defense assistance. Conversely, Mozi also warns a general of Qi that attacking Lu will injure both sides and that such a wrong eventually returns to the aggressor. He cites historical examples of serial conquerors who were eventually defeated and executed by alliances of other feudal lords (49/4-8). He counsels the King of Qi that he will incur ill fate for the invasion (49/8-11). A natural implication of these exchanges is that a belligerent state is unworthy of defense assistance. As to the Annals' claim that in practice offensive and defensive warfare are one and the same, surely a meaningful distinction can be drawn between the two. Offensive strategies or tactics can of course be employed toward defensive ends, but an overlap in strategies and tactics does not erase the difference between aggression and defense. The Mohists could coherently denounce 
unprovoked war for aggressive ends while allowing the use of offensive tactics for defensive ends.

One difference between the Mozi and the Annals is that only the latter spells out jus in bello requirements for the conduct of a rightful punitive invasion. ${ }^{44}$ The Mozi writers are more concerned with the question of jus ad bellum, or when such an invasion is justified. The Annals' implicit position on jus ad bellum is that punitive intervention is justified when the rulers of a state diverge from "sagely institutions" and "old canons," engage in heavy, capricious taxation and confiscation of property, and administer rewards and punishments unjustly. Arguably, however, these conditions set the bar much too low. Even if these are signs of misrule, it is difficult to see how a punitive war could be justified merely on the grounds that the targeted state has modified traditional institutions, levies onerous taxes, and operates an unfair or abusive criminal justice system. Many modern states have exhibited similar features without their neighbors deeming themselves justified in invading and removing their leadership by force.

The Mozi is less specific about the crimes that might justify punitive missions. As we have seen, the text accuses the tyrants Jie and Zhou of torturing and massacring the innocent. By our lights, these atrocities might justify humanitarian intervention. More typically, however, Mohist writings simply claim that the targets of punitive missions were "disorderly." The Mohists may devote less attention to specifying justificatory criteria for punitive missions because they expect Heaven itself to unambiguously indicate when punitive war is justified. Indeed, through their appeal to unequivocal, miraculous signs of Heaven's mandate, they set the bar for justified punitive war impracticably high. In its original context, however, this stringent requirement of divine sanction may have been a shrewd solution to a conspicuous risk arising from the doctrine of just punitive war. A warlike ruler could all too easily excuse illegitimate aggression on the pretext that it is punitive rather than aggressive war. $^{45}$ If justified punitive missions require divine sanction, this pretext is largely ruled out, since in practice such missions can never fulfill the justifying condition.

Absent miraculous omens indicating Heaven's mandate, what would justify punitive war? This question is taken up in a dialogue in which Mozi dismisses a proposed justification for a punitive expedition.

Lord Wen of Lu Yang said, "Sir, why stop me from attacking Zheng? My attacking Zheng follows Heaven's intent. For three generations, the people of Zheng have murdered their ruler. Heaven has punished them, causing three years of scarcity. I will assist Heaven in its punishment."

Our master Mozi said, "For three generations, the people of Zheng have murdered their ruler and Heaven has punished them, causing three years of scarcity. Heaven's punishment has been sufficient. Yet now you raise an army to attack Zheng, saying 'My attacking Zheng is following Heaven's intent.' As an analogy, suppose there were a man whose son was strong but useless, so his father whipped him with a bamboo cane. The neighbor's father [then] beat him with a wooden staff, saying, 'My beating him is following his father's intent.' How would this not be perverse?" (49/16-20)

Lord Wen's claim echoes the heralds' announcement in the Annals that the invading army is following Heaven's Way. The passage implies several intriguing points that 
help to flesh out the Mohist just war theory. The grounds for a legitimate punitive war cannot be simply that the offending state is disorderly or has committed crimes. A stronger justification is needed, such as divine sanction or the likelihood that punitive war would produce a significantly greater total balance of benefit over harm. Without miraculous portents, the very evidence that Heaven is displeased with a state - such as that the state suffers from scarcity - is at the same time evidence that Heaven itself has already punished it. Further punishment is redundant.

Mozi's remarks also imply inchoate recognition of a further condition in just war theory, proportionality of the means of justified war to the ends. If the end is to punish Zheng, then Lu Yang's invasion violates proportionality, as Heaven has already dealt out sufficient punishment. The passage can be read too as implying a condition of last resort, by which war cannot be justified as long as peaceful alternatives remain. For a consequence of Mozi's remarks is that a punitive mission could be justified only if one first waited to see whether Heaven itself would punish the offender. Hasty intervention without Heaven's mandate would never be justified.

More important, this example again raises the problem of proper authority for a punitive mission. As we have seen, the word for such missions, "zhu 誅," also refers to criminal punishment. A prominent rhetorical strategy in the Annals and other texts is to draw analogies between punitive war, criminal justice in political society, and even child discipline in the home. Criminal punishment can be justified only if carried out by a proper authority. By analogy, then, punitive warfare can be justified only if carried out by a legitimate authority. So if punitive warfare is analogous to criminal punishment, on what authority may the ruler of one state punish the ruler of another? As the Mencius explains, only an emperor or "an official of Heaven" could have the legitimate authority to punish an unfit ruler (Mengzi 14.2, 4.8). The ruler's peers do not. Without divine sanction, then, Lord Wen has no authority to punish a neighboring state. Just as we lack the proper authority to punish a neighbor's child, the sovereign of one state lacks the proper authority to punish wrongdoers in another-let alone to punish its ruler, his political equal.

Alternatively, the pre-Han conception of just punitive war might be interpreted as implicitly denying the existence of state sovereignty or the significance of international boundaries. Distinct states are regarded as parts of a greater entity, tian xia 天下 ("all under heaven," or the human, social world), subject to the authority of an actual or potential emperor, who is himself accountable to the authority of Heaven. Conceptually, perhaps early Chinese thinkers do not really recognize war between sovereign states as such. To them, interstate violence might fall within the purview of criminal justice. ${ }^{46}$ Illegitimate aggression, whether against other states or one's own subjects, amounts to a crime to be punished. Legitimate war for offensive ends is a punitive activity premised on treating the rulers of offending states as if they were domestic criminals. A just punitive invasion thus purports to be an exercise of legitimate authority, rather than — as we might understand it - a means of establishing authority over a conquered territory. In principle, to undertake a just punitive mission, the aggressor must already hold the appropriate authority, through Heaven's mandate. ${ }^{47}$ Hence Mozi's response to Lord Wen: Wen purports to act on behalf of Heaven, but nothing supports this claim to celestial authority. ${ }^{48}$

By the middle of the Warring States era, with the near-total decline of the Zhou rump empire, the requirement that a punitive invader hold proper authority was gradually subverted by the idea that a virtuous new emperor might arise from among the rulers of the seven rival warring states. ${ }^{49}$ A new emperor's success in punishing other states and uniting them under his rule would confirm that he had earned the 
mandate of Heaven and possessed rightful authority. Of course, any such claim to divine authority would be spurious. In practice, the last warlike ruler left standing would simply declare himself the virtuous recipient of Heaven's mandate, whether or not his supposedly punitive aggression against other states was justified. In this regard, the doctrine of just arms (yi bing) could easily degenerate into a circular, ex post facto apology for the aggression of whichever warlord managed to bludgeon his rivals into submission. ${ }^{50}$ In the absence of an established imperial order, then, without the divine portents the Mohists demand, the doctrine of just punitive war could probably never legitimately justify aggression. The "impossible test" of divine sanction that the Mozi sets for legitimate punitive warfare in fact perfectly reflects the internal logic of the doctrine of just arms. ${ }^{51}$ The Mencius is right: peers cannot legitimately punish one another.

Punitive war $(z h u)$ is a category of justifiable war for offensive ends. If we set aside punitive war on the grounds that the justification criteria are too difficult to satisfy, might there remain other categories of justifiable offensive war? Two passages in the Mozi hint at a conception of justified retributive war, using phrases referring to vengeance or retribution (such as "bao chou 報隹售”) rather than punishment (49/5-8, 18/27-41). King He Lü of Wu attacked neighboring states to the east, west, and north. The lords of several states then avenged this aggression, capturing his state and mutilating his corpse. ${ }^{52} \mathrm{Zhi} \mathrm{Bo}$, a minister of Jin, overthrew several rival houses until the rulers of three states allied together to avenge them, again ruining his state and defiling his corpse. ${ }^{53}$ Both stories depict allied offensive campaigns against a serial aggressor. Although the Mozi does not explicitly endorse these campaigns as just, it does not condemn them and indeed implies that such retribution is inevitable (49/8). Without explicitly presenting a conception of just retributive war, then, the Mozi presents ideas that can easily be developed into one. Like just punitive war, a just war of retribution would be waged for just cause, in response to illicit aggression, and with right intention, to avenge injury and remove the aggressor. ${ }^{54}$ Presumably it would restore order and eliminate the threat of continued aggression. Retributive war sidesteps the problem of authority raised by punitive war. As depicted in the stories, the feudal lords do not appeal to divine sanction to justify retributive attacks. Rather, they ally together and act in retaliation (49/5-8) or preëmptive self-defense (18/37), since the repeat aggressor poses a threat to all. Although the idea is not developed, these passages may hint at an inchoate conception of approval by an international community as providing authority for a just offensive war of retribution. This conception of just retributive war coheres well with - and is perhaps best considered an extension of - the Mohist notion of just defensive war, especially since for the Mohists defense includes the defense of allies and of unallied innocent states.

Besides the explicit notion of punishment $(z h u)$, early texts also implicitly present a consequentialist standard for justified warfare. Xunzi contends that it is benevolent and just to take up arms to end violence and eliminate harm (15/67-69). The Sima Fa holds that going to war to end warfare is justified (D1/45/3-4). The Mohists are committed to a consequentialist ethics in which what is right is determined by what produces the greatest benefit for all. Against the backdrop of these views, one could also attempt to justify offensive war in some circumstances by arguing that it realistically promises to yield greater overall benefit than refraining from war. Indeed, as we have seen, this consequentialist standard probably underwrites the Mohist advocacy of defensive war. In the case of offensive war, however, the standard will probably be difficult to meet. Consider the Mohist 
conception of benefit as constituted by material wealth, a flourishing population, and social order. ${ }^{55}$ Offensive war expends resources, reduces the population, and disrupts social order. Thus by the Mohists' lights, offensive military expeditions can be justified only if these harms are outweighed by the expected benefit, such as prevention of further harms by removing a belligerent, unfit leader. We saw earlier that one Mozi passage favors diplomacy over defensive warfare, a stance that may reflect an implicit condition of last resort: the harms of warfare are so great that it can be justified only when no alternative is viable. This conservative stance toward defensive war suggests that the Mohists would adopt at least as cautious a stance toward consequentialist arguments for offensive war. If any alternative means of promoting benefit are available, they will probably be more justified than war. Indeed, for the Mohists the justification for political authority itself lies in the benefit to all that ensues from the existence of the state. The social harms caused by reckless military exploits thus undermine a ruler's claim to rightful political authority and in turn his authority to order his army into war.

The Mozi passage considered above about praiseworthy motives for aggressive war indirectly bears on this issue. Suppose a ruler's motive for offensive war is laudable - he seeks a reputation for justice and virtue, for instance. Still, according to the Mozi, such a ruler should forgo war and devote himself instead to the "giant task of benefiting all the world" (19/61-62). Presumably the ruler would contemplate war only if beneficial consequences were likely. The passage does not directly rule out the idea that offensive war could have good consequences. But it suggests other, more effective ways to benefit the world - trustworthy diplomacy, deploring immoral conduct by large states, contributing to the defense of small states, generously distributing foreign aid to the needy, and governing one's own state with tolerance and kindness (19/56-61). An implication is that more beneficial alternatives to offensive war will usually be available. In principle, then, offensive war on humanitarian grounds might sometimes be justified, but such cases will be rare.

To sum up, the Mohists probably hold that, without miraculous omens indicating divine sanction, punitive warfare is practically never justified. To the Mohists, the criteria suggested by the Annals are too lax. Offensive military intervention for morally good ends, such as promoting the benefit of all, removing a threat, or reversing the harms done to a conquered territory, could conceivably sometimes be justified. However, the criteria of justification would be stringent. They would probably include that the targeted state had committed aggression or atrocities, that war was the only plausible means of achieving the morally good ends intended, and that without intervention the offending state was unlikely to suffer misfortune proportionate to the harms it had caused. These conditions would likely only rarely be met.

\section{Conclusion}

Discussions of war in Warring States China generally assume that war in defense of an innocent state is justified, and so debate focuses on the conditions for a just offensive war. The consensus is that an offensive campaign against a state can in principle be justified as a response to its aggression against other states or its own subjects. The potential for significant disagreement arises concerning three points: whether to frame such a campaign conceptually as punishment, retribution, or defense; on what authority one state can intervene in the affairs of another; and what level of aggression is required to justify intervention. 
The prevailing conception of just offensive war grounds it in an analogy between just war and criminal punishment. Some early texts assume this analogy renders the grounds for such wars uncontroversial. In fact, however, this way of framing the issue prevents early Chinese theorists from squarely addressing the conditions under which one sovereign state might legitimately attack another. For without sanction from some higher authority, purportedly independent states lack the authority to punish one another. The terminology of "punishment" also reflects a widespread vagueness in Warring States political thought concerning the status of independent states. Are they autonomous political entities, which must respect each other's sovereignty, or are they only jurisdictions within a greater whole, "all under heaven"? Are the residents of such states merely subjects of a local lord, who can be expected to willingly desert a corrupt ruler, or are they members of a sovereign nation, to which they remain loyal even if governed by a contemptible leader?

A more promising approach to justifying offensive war may be to frame it as following from a commitment to defend or restore innocent states, undertaken on the authority of an alliance of states pledged to mutual protection. The underlying justification - for both the Mohists and others-would be that such mutual defense promotes the benefit of all the world. This approach does not directly apply to cases in which a state mistreats its own subjects. However, it could be extended into a commitment to defend innocent subjects from their own government when necessary.

A more vexing question is exactly what circumstances justify an offensive response against a state with a record of serial aggression against other states or its own subjects. Of the texts examined here, it seems no coincidence that the Mozi, which sets the strictest criteria for justifying war, also depicts the horrors of war more starkly than other sources. ${ }^{56}$ Accordingly, the Mozi also seems more sensitive to the proportionality of the means of war to its ends. The Mengzi, the Xunzi, and the Annals are all disconcertingly sanguine about the purported bloodlessness of a just punitive war and the supposedly warm welcome a just army can expect. Perhaps the Mozi sets the bar too high, making offensive humanitarian intervention too difficult to justify. But the Annals and the Xunzi are almost certainly too permissive in licensing punitive war and unrealistically optimistic about its consequences. Among these texts, the Mozi comes closest to reflecting the actual complexity of the issue of justifying military aggression for humanitarian ends. The Mohists are probably also correct in holding that the potential harms of aggression are so great that it can seldom be justified. $^{57}$

\section{Bibliography}

Fraser, Chris. "Mohism." The Stanford Encyclopedia of Philosophy (Spring 2014 Edition), edited by Edward Zalta, http://plato.stanford.edu/archives/spr2014/entries/mohism/.

Godehardt, Nadine. "The Chinese Meaning of Just War and Its Impact on the Foreign Policy of the People's Republic of China." GIGA Working Papers 88. Hamburg: German Institute of Global and Area Studies, 2008.

Graff, David. "The Chinese Concept of Righteous War.” In The Prism of Just War, edited by Howard Hensel, 195-216. Burlington: Ashgate, 2010.

Hung, William, ed. A Concordance to Mozi. Harvard-Yenching Institute Sinological Index Series, Supplement no. 21. Beijing: Yenching University Press, 1948. 
Hung, William, ed. A Concordance to Zhuangzi. Harvard-Yenching Institute Sinological Index Series, Supplement no. 20. Cambridge, Ma.: Harvard University Press, 1956.

Hung, William, ed. A Concordance to Xunzi. Harvard-Yenching Institute Sinological Index Series, Supplement no. 22. Cambridge, Ma.: Harvard University Press, 1966.

Kane, Thomas. "Inauspicious Tools: Chinese Thought on the Morality of Warfare." In Just War in Comparative Perspective, edited by Paul Robinson, 139-152. Burlington: Ashgate, 2003.

Knoblock, John, and Jeffrey Riegel, tr. The Annals of Lü Buwei. Stanford: Stanford University Press, 2000.

Lau, D. C., tr. Lao Tzu Tao Te Ching. London: Penguin, 1963.

Lau, D. C., Ho Che Wah, and Chen Fong Ching, eds. A Concordance to the Lunyu. Hong Kong: Commercial Press, 1995.

Lau, D. C., Ho Che Wah, and Chen Fong Ching, eds. A Concordance to the Mengzi. Hong Kong: Commercial Press, 1995.

Lau, D. C., and Chen Fong Ching, eds. A Concordance to the Shangjunshu. Hong Kong: Commercial Press, 1992.

Lau, D. C., and Chen Fong Ching, eds. A Concordance to the Militarists. Hong Kong: Commercial Press, 1992.

Lewis, Mark. "The Just War in Early China." In The Ethics of War in Asian Civilizations, edited by Torkel Brekke, 185-200. Oxon: Routledge, 2006.

Lorge, Peter. "Introduction." In Debating War in Chinese History, edited by Peter Lorge, 1-11. Leiden: Brill, 2013.

Mosely, Alexander. "Just War Theory." In The Internet Encyclopedia of Philosophy, edited by James Fieser and Bradley Dowden. http://www.iep.utm.edu/justwar/. Published February 2009.

Orend, Brian. "War." In The Stanford Encyclopedia of Philosophy (Fall 2008 Edition), edited by Edward Zalta. http://plato.stanford.edu/archives/fall2008/entries/war/. Published 2008.

Orend, Brian. The Morality of War. Second edition. Peterborough, Ont.: Broadview Press, 2013.

Sawyer, Ralph, tr. The Seven Military Classics of Ancient China. Boulder: Westview, 1993.

Stroble, James. "Justification of War in Ancient China." Asian Philosophy 8 (1998): $165-190$.

Van Els, Paul. "How to End Wars with Words: Three Argumentative Strategies by Mozi and His Followers." In The Mozi as an Evolving Text: Different Voices in Early Chinese Thought, edited by Carine Defoort and Nicolas Standaert, 69-94. Leiden: Brill, 2013.

Van Els, Paul. "Righteous, Furious, or Arrogant? On Classifications of Warfare in Early Chinese Texts." In Debating War in Chinese History, edited by Peter Lorge, 13-40. Leiden: Brill, 2013.

Van Norden, Bryan. Virtue Ethics and Consequentialism in Early Chinese Philosophy. Cambridge: Cambridge University Press, 2007.

Wong, Benjamin, and Hui-chieh Loy. "War and Ghosts in Mozi's Political Philosophy." Philosophy East and West 54 (2004): 343-363.

Yan, Changyao 顏昌嶢. Guanzi Jiaoshi 管子校釋. Changsha: Yuelu, 1996. (Original preface 1924.) 
Zhang, Yuanji 張元濟, ed. Xugu Yicongshu 續古逸叢書, vol. 89. Shanghai:

Commercial Press, 1935.

\section{Notes}

1 See Mark Lewis, "The Just War in Early China," in The Ethics of War in Asian Civilizations, edited by Torkel Brekke (Oxon: Routledge, 2006), 191-192. Lewis suggests that this theory of just arms formed the core of later Chinese views of justified warfare.

${ }^{2}$ See Peter Lorge, "Introduction," in Debating War in Chinese History, edited by Peter Lorge (Leiden: Brill, 2013), 10.

${ }^{3}$ Brian Orend, The Morality of War (Peterborough: Broadview Press, 2013), 1012.

${ }^{4}$ Orend, Morality, 15-16.

${ }^{5}$ For sample discussions of these widely affirmed criteria, along with those for jus in bello, see Alexander Mosely, "Just War Theory," in The Internet Encyclopedia of Philosophy (2009), and Brian Orend, "War," in The Stanford Encyclopedia of Philosophy (2008).

${ }^{6}$ References to the Zhuangzi give chapter and line numbers in William Hung, ed., A Concordance to Zhuangzi (Cambridge: Harvard University Press, 1956).

7 Lewis, "Just War," 187.

${ }^{8}$ References to the Mozi give chapter and line numbers in William Hung, ed., $A$ Concordance to Mozi (Beijing: Yenching University Press, 1948).

${ }^{9}$ Bryan Van Norden, Virtue Ethics and Consequentialism in Early Chinese Philosophy (Cambridge: Cambridge University Press, 2007), 174.

10 Van Norden, Virtue Ethics, 176, makes this observation.

11 For a detailed account of each argument, see Paul Van Els, "How to End Wars with Words: Three Argumentative Strategies by Mozi and His Followers," in The Mozi as an Evolving Text: Different Voices in Early Chinese Thought, edited by Carine Defoort and Nicolas Standaert (Leiden: Brill, 2013), 69-94.

12 The triads are ten sets of three essays, one for each of the ten key Mohist doctrines. The three essays in each set bear the same title. For further information, see Chris Fraser, "Mohism," The Stanford Encyclopedia of Philosophy (Spring 2014 Edition), edited by Edward Zalta, http://plato.stanford.edu/archives/spr2014/entries/mohism/.

${ }^{13}$ There is a remarkable parallel between the Mohist point here and Augustine's anecdote about the pirate in City of God, Book 4, Chapter 4. Challenged by Alexander the Great to explain his conduct, the pirate replied it was of the same kind as Alexander's own, the only difference being that piracy committed on a petty scale makes one a robber, while on a vast scale it makes one an emperor. See Augustine, City of God, tr. Marcus Dods (New York: Random House, 2000), 113. I thank my colleague Uwe Steinhoff for pointing out the parallel to me. 
14 For instance, Lewis, "Just War," 188, neglects the Mohist discussion of punitive warfare.

${ }^{15}$ Mozi 9/13-14. See too 9/30-31, 12/40, and 37/42-43. These passages have many similarities in style and vocabulary and probably all date to roughly the same phase in the development of the Mozi corpus as the apology for the sage-kings' wars. An interesting question is to what extent these references to punitive war might be purely rhetorical, since - as we will see - for the Mohists in practice such wars can almost never be justified.

16 "How to End Wars," 77.

17 This point is emphasized by Benjamin Wong and Hui-chieh Loy, "War and Ghosts in Mozi's Political Philosophy," Philosophy East and West 54 (2004): 354-55. See too Van Els, "How to End," 84-91.

18 See Van Els, "How to End," 91.

19 Citations to the Annals give section numbers in John Knoblock and Jeffrey Riegel, tr., The Annals of Lü Buwei (Stanford: Stanford University Press, 2000).

${ }^{20}$ See sections $8,22,66,68,73$, and 81 . Citations to the Daodejing give section numbers in the traditional text. For a translation, see D. C. Lau, tr., Lao Tzu Tao Te Ching (London: Penguin, 1963).

21 David Graff argues that for the Daodejing, arms may be used legitimately only in response to aggression by others. See Graff, "The Chinese Concept of Righteous War," in The Prism of Just War, edited by Howard Hensel (Burlington: Ashgate, 2010), 198. Thomas Kane agrees that the text counsels avoiding war whenever possible, but underscores its pragmatic, flexible stance toward the use of arms. See Kane, "Inauspicious Tools: Chinese Thought on the Morality of Warfare," in Just War in Comparative Perspective, edited by Paul Robinson (Burlington: Ashgate, 2003), 143.

22 The Book of Lord Shang is a major early source for classical Chinese "Legalism" or "Realism." Citations are to D. C. Lau and Chen Fong Ching, eds., $A$ Concordance to the Shangjunshu (Hong Kong: Commercial Press, 1992).

${ }^{23}$ The Guanzi is a compilation of texts from the ancient state of Qi representing different lineages of thought. It is traditionally classified as "Legalist" because many - though by no means all — of its parts have a vaguely Legalist doctrinal bent. For the passage referred to here, see Yan Changyao, Guanzi Jiaoshi (Changsha: Yuelu, 1996), 179.

${ }^{24}$ Yan, Guanzi, 243-244.

${ }^{25}$ Citations are to D. C. Lau and Chen Fong Ching, eds., A Concordance to the Militarists (Hong Kong: Commercial Press, 1992). For a discussion and translation of the Sima Fa and the other military texts mentioned below, see Ralph Sawyer, tr., The Seven Military Classics of Ancient China (Boulder: Westview, 1993).

${ }^{26}$ Citations are to Lau and Chen, A Concordance to the Militarists.

${ }^{27}$ See Paul Van Els, "Righteous, Furious, or Arrogant? On Classifications of Warfare in Early Chinese Texts," in Debating War in Chinese History, edited by Peter Lorge (Leiden: Brill, 2013), 19.

28 Zhang Yuanji, ed., Three Strategies of Huang Shi Gong, in Xugu Yicongshu (Shanghai: Commercial Press, 1935), Vol. 89, 21.

${ }^{29}$ Zhang Yuanji, ed., Six Secret Teachings, in Xugu Yicongshu, Vol. 89, 66.

${ }^{30}$ Citations are to Lau and Chen, A Concordance to the Militarists.

31 References to the Analects cite section numbers in D. C. Lau, et al., eds., $A$ Concordance to the Lunyu (Hong Kong: Commercial Press, 1995). 
${ }^{32}$ Citations to Mengzi give section numbers in D. C. Lau, et al., eds., $A$ Concordance to the Mengzi (Hong Kong: Commercial Press, 1995).

${ }^{33}$ Graff rightly calls attention to Mencius's conviction that just wars involve little or no bloodshed ("The Chinese Concept," 200).

${ }^{34}$ See Graff, "The Chinese Concept," 204-205.

${ }^{35}$ Citations to Xunzi give chapter and line numbers in William Hung, ed., A Concordance to Xunzi (Cambridge: Harvard University Press, 1966).

${ }^{36}$ On this point, see too James Stroble, "Justification of War in Ancient China," Asian Philosophy 8 (1998), 174.

${ }^{37}$ This paragraph paraphrases key points from Xunzi 15/59-66.

${ }^{38}$ The phrase "force multiplier" is Graff's. See Graff, "The Chinese Concept," 208-209.

${ }^{39}$ Graff aptly raises this concern with respect to the military texts ("The Chinese Concept," 209).

${ }^{40}$ See Annals 7/2.1-7/2.4. References to the Annals give section numbers in John Knoblock and Jeffrey Riegel, tr., The Annals of Lü Buwei (Stanford: Stanford University Press, 2000).

${ }^{41}$ This inchoate theory of political authority as grounded in victory in combat may be unique in early Chinese thought. A more common theory of the origin of political authority grounds it in good consequences for society. Both the Mozi and the Xunzi offer such consequentialist theories.

${ }^{42}$ See Stroble, "Justification of War," 175.

${ }^{43}$ This incisive observation is due to Nadine Godehardt, "The Chinese Meaning of Just War and Its Impact on the Foreign Policy of the People's Republic of China," GIGA Working Papers 88 (Hamburg: German Institute of Global and Area Studies, 2008), 19.

${ }^{44}$ Graff, "The Chinese Concept," 208, suggests that the Mohists reject the idea of jus in bello, quoting a passage that criticizes a Ruist description of humane conduct toward retreating soldiers. However, the passage cited (Mozi 39/21-26) indicates only that morally vicious soldiers targeted by punitive warfare should not be spared. It does not imply that the Mohists reject jus in bello guidelines for humane conduct toward morally worthy opponents or toward innocents.

${ }^{45}$ Wong and Loy raise this worry ("War and Ghosts," 347), as does Graff ("The Chinese Concept," 209-210).

${ }^{46}$ Godehardt aptly captures these features of the classical Chinese worldview, noting that the early Chinese tradition lacks a distinction between international and domestic conflict, both being considered disruptions of social order, and that a just war waged by an emperor is more similar to a police action than to a military one. See Godehardt, "The Chinese Meaning of Just War," 24, 26.

${ }^{47}$ Stroble, "Justification of War," 175, underscores these points.

${ }^{48}$ Graff, "The Chinese Concept," 196, suggests that the issues of competent authority for warfare and proportionality of the means of warfare to the ends remain undeveloped or ambiguous in classical Chinese discourse. While no explicit consensus emerged on these issues, Mohist writings can plausibly be interpreted as addressing them reasonably.

${ }^{49}$ See Graff, "The Chinese Concept," 205.

${ }^{50}$ Stroble, "Justification of War," 175, and Graff, "The Chinese Concept," 208, both stress this point. 
51 On the "impossible test," see Van Els, "How to End Wars," 91, who credits the phrase to Michael Nylan.

${ }^{52}$ In one version of the story, He Lü is defeated by King Goujian of Yue (18/3233). In another, he is defeated by the "various lords" (49/6).

53 A similar situation is depicted in Mencius (2.11). After King Xuan of Qi conquers Yan, the lords of several states plan to ally together to attack Qi and rescue Yan.

54 Mencius (6.5) justifies the sage-king Tang's intervention against the ruler of Ge on related grounds, claiming that he acted in retribution for the murder of a boy carrying supplies to laborers he had dispatched to assist Ge. The text implies that the aim and justification of Tang's eleven invasions of other states was retribution against corrupt rulers for their misconduct toward the common people.

55 See Fraser, "Mohism," sect. 7.

${ }^{56}$ One exception is a passage in the Annals that refers to corpses filling the plains and valleys and exposed skeletons piled as high as mountains (7/4.2).

${ }^{57}$ I am grateful to Uwe Steinhoff for constructive comments and for saving me from a pair of errors. 